\title{
DOES PERSONALITY PLAY A ROLE IN COMPUTER INFORMATION SYSTEMS COURSE PERFORMANCE?
}

\author{
S.E. Kruck, James Madison University, kruckse@jmu.edu \\ Patricia Sendall, Merrimack College, patricia.sendall@merrimack.edu \\ Wendy Ceccucci, Quinnipiac University, wendy.ceccucci@quinnipiac.edu \\ Alan Peslak, Penn State University, arp14@psu.edu \\ Scott Hunsinger, Appalachian State University, hunsingerds@appstate.edu
}

\begin{abstract}
This study represents an analysis of student performance in computer information systems (CIS) courses and the potential influence of Jungian personality traits on academic success in CIS courses. For this study, academic success is measured by grades achieved. The MBTI measurement scale was self-analyzed by students in CIS courses from fall 2008 through spring 2013. The data showed a statistically significant correlation between various personality dichotomies of the type (Extraversion-Introversion, Sensing-Intuition, Thinking-Feeling, and JudgingPerceiving) and higher grades scores. The results of this study indicate that course performance of groups of students are different relative to their personality type. In this study, Thinking type students performed better than Feeling types, and Judgers performed better than Perceivers.
\end{abstract}

Keywords: MBTI, Meyers-Briggs, Computer Information Systems, personalities

\section{INTRODUCTION}

A number of studies have been published that attempt to determine how the Myers-Briggs Type Indicator (MBTI) measurement scale can be used to predict outcomes in a number of areas in business and in academe. These studies include, but are not limited to; students' academic preference and performance [1]; students' choice of major [10]; human factors in accounting information systems $[2,19]$; predictors of success in student team-based information technology (IT) projects [10]; predictors of success for computer programmers [16]; and professional information systems work [8]; predictors of success of information technology professionals [9] and managerial attributes, behaviors and effectiveness [5]. This study seeks to determine whether or not the MBTI can be used to predict the academic success of students who enroll in computer information systems courses. For this study, academic success is measured by grades achieved by the students.

\section{BACKGROUND}

Personality awareness is a desirable "soft skill" for IT professionals. Studies have shown that not only must technologists possess "hard" skills in programming, analysis and design, but they must also know how to communicate both written and orally. Students can significantly benefit from not only understanding their own particular characteristics, but also the characteristics of others [8]. According to Weldon [19], "Computer literacy isn't enough. IS managers and pros [sic] need emotional literacy to build teams and work well with users."

Between 1942-1944, an early version of the MBTI personality indicator was developed by a mother-daughter team, Katherine Briggs and Isabel Briggs Myers. The instrument, based on Carl G. Jung's typological approach to personality, is represented by the following four dichotomies (bipolar dimensions where each pole represents an opposite preference). The first three are based on Jung's work; the last was later introduced by Myers and Briggs: Extraversion - Introversion, Sensing - Intuition, Thinking - Feeling and Judging - Perceiving.

Based on Jung's typology (1971), individuals can be classified using two mental functions (sensing-intuition and thinking-feeling), and attitude (extraversion-introversion). The fourth parameter (judging-perceiving) helps to determine the dominant function. David Keirsey and Marilyn Bates popularized the MBTI system in their 1980's book, Please Understand Me [6]. 
All possible permutations of the 4 criteria above define 16 different personality types (Table 1). Each type can be assigned a name (personality type formula), as an acronym of the combination of the 4 dimensions that defines the Personality Type. For example: ISTJ: Introvert, Sensing, Thinking, Judging and ENFP: Extravert, iNtuitive, Feeling, Perceiving. Appendix A provides a detailed description of each of the 16 personality types [11].

Table 1: MBTI Personality Types

\begin{tabular}{||l|l|l|l||}
\hline \hline ISTJ & ISFJ & INFJ & INTJ \\
\hline ISTP & ISFP & INFP & INTP \\
\hline ESTP & ESFP & ENFP & ENTP \\
\hline ESTJ & ESFJ & ENFJ & ENTJ \\
\hline
\end{tabular}

Source: The Myers \& Briggs Foundation [12]

Some organizations have attempted to correlate the 16 personality dispositions to choice of academic major. In MBTI and Major Choice, the University of Toledo [17] organized majors by personality type based on DiTiberio \& Hammer's [3] Introduction to Type in College and Isabel Briggs Myers' 1998 Introduction to Type (Appendix B). Personality types that were found to be suited toward technology-based majors were: Information Systems (INTP, ESTP); Information Technology (ENTP); and generic Technology (INTJ, ENTP). Personality types for Computer Science or Computer Information Systems were not provided.

McPherson \& Mensch [11] sought to determine if there was a correlation between personality type and information technology students' choice of major. They defined information technology to include Business Information Systems (BIS), Computer Information Systems (CIS), and Management Information Systems (MIS). They determined that a relationship did in fact exist, with a significance level of .001, between personality type and choice of major. The top three personality types were drawn toward the following majors:

- $\quad$ BIS: ESTJ, ESTP, ESFJ

- MIS: ISTJ, ESTJ, ESFJ

- CIS: ISTJ, INTJ, ISTP

The findings concluded that the dominant personality dispositions for those who chose BIS were extrovert/sensing; MIS were sensing/judging; and CIS were introvert/thinking.

Sterling and Brinthaupt [16] studied twenty university computer science (16) and computer information systems (4) (CIS) faculty members (15 males, 5 females) to determine personality types of the participants. The group predicted that the majority would fall into the ESTJ category. However, what they found, based on the responses of the participants, was that the programmers tended to be ENTPs, with the majority being thinking-perceiving types.

According to Montequin, Balsera, Fernandez \& Nieto [12], ISTJ and INTJ are the most common personality types found in the computer industry. Lyons (1985) concluded that IT people have very different MBTI results as compared to the general public. Teague (1998) found "preferred" MBTI personality types for various technology jobs. The top characteristics were:

- System Analysts: ENFP, ENTP, ENFJ, ENTJ

- Computer Designers: INTJ, INTP, ENTP, ENTJ

- Computer Programmers: ISTJ

The Institute for Management Excellence used MBTI to look at people who tend to migrate toward the computerrelated industry. This group was defined as corporate Information Services, Information Systems, Information Technology or Data Processing. They found that computer professionals and managers tended to be more introverted, slightly more intuitive, more thinking oriented and somewhat more judging (INTJ).

\section{RESEARCH METHODOLOGY}

The study centered upon the following research question: Does personality type have an effect on computer information systems course grades. 
The research hypotheses to be tested are as follows:

H1: There is no significant difference between the grades for the 16 MBTI types.

$\mathrm{H} 2$ : There is a significant relationship between grade and the E-I index score.

H3: There is a significant relationship between the grade and the S-N index score.

H4: There is a significant relationship between the grade and the T-F index score.

H5: There is a significant relationship between the grade and the J-P score.

\section{RESULTS}

The MBTI personality indicator was distributed to students enrolled in CIS courses at a public university located in Virginia. Five years of data were collected, from 2008 through 2013. Each semester the MBTI was given to undergraduate and graduate CIS courses. Students from 30 classes were examined with the following course distribution: Undergraduate: Programming (14), Enterprise Architecture (7), and Computer Security Management (4), Graduate: Managerial Information Systems (5). The total number of valid tests for analysis was 864.

While the majority of students were CIS majors, there were a number of students that were taking the course as an elective or for a minor. The distribution of majors and their corresponding MBTI index are given in Table 2.

Table 2. Sample MBTI Scores by Major

\begin{tabular}{|c|ccccccccccc|c|}
\hline MBTI & Acct & CIS & CS & Econ & Fin & lbus & Mgt & Mkt & MBA & Other & Total \\
\hline ENFJ & 27 & 60 & 1 & 3 & 18 & 3 & 9 & 10 & 16 & 13 & 160 \\
ENFP & 5 & 7 & 1 & 1 & 3 & & 2 & 2 & 1 & 4 & 26 \\
ENTJ & 19 & 53 & 1 & 1 & 13 & 3 & 9 & 5 & 12 & 9 & 125 \\
ENTP & & 3 & & & 6 & 1 & & & 2 & 4 & 16 \\
ESFJ & 28 & 55 & & 2 & 17 & & 7 & 6 & 5 & 22 & 142 \\
ESFP & 1 & 9 & & 1 & 3 & & & 2 & & 7 & 23 \\
ESTJ & 19 & 43 & & 1 & 12 & 3 & 8 & 4 & 8 & 11 & 109 \\
ESTP & 1 & & & & 3 & & & & 1 & 1 & 6 \\
INFJ & 5 & 14 & & & 1 & 1 & 1 & 1 & 4 & 11 & 38 \\
INFP & & 2 & & & & & & & 2 & 2 & 6 \\
INTJ & 12 & 24 & 2 & 3 & 3 & & 6 & 2 & 17 & 14 & 83 \\
INTP & 1 & & 2 & & 1 & 1 & 1 & & & 1 & 7 \\
ISFJ & 14 & 19 & & & 4 & & 3 & 1 & 6 & 4 & 51 \\
ISFP & 1 & 6 & & 1 & & & & & & 3 & 11 \\
ISTJ & 11 & 17 & 1 & & 5 & 1 & 5 & 2 & 7 & 7 & 56 \\
ISTP & 1 & 2 & & & 1 & & & & & 1 & 5 \\
\hline Total & 145 & 314 & 8 & 13 & 90 & 13 & 51 & 35 & 81 & 114 & 864 \\
\hline
\end{tabular}

The above results do not correspond with the prior research. The results from the University of Toledo [17], found that the personality types most suited toward technology-based majors were: Information Systems (INTP, ESTP); Information Technology (ENTP); and generic Technology (INTJ, ENTP). Montequin et al [11] found that ISTJ and INTJ were the most common personality types found in the computer industry. Our survey found that over fifty percent of the CIS majors were either ENFJ (19\%), ESFJ (17\%) or ENTJ (17\%). 


\section{Issues in Information Systems \\ Volume 15, Issue II, pp. 383-392, 2014}

Figure 1 shows the breakdown of each dichotomy for the CIS majors. A high percentage of the majors were Extroverts (73\%) and Perceptive types (91\%). One reason for the change in personality traits could be the changing attitudes towards the field of technology. The technology field has become more attractive and offers more job opportunities.

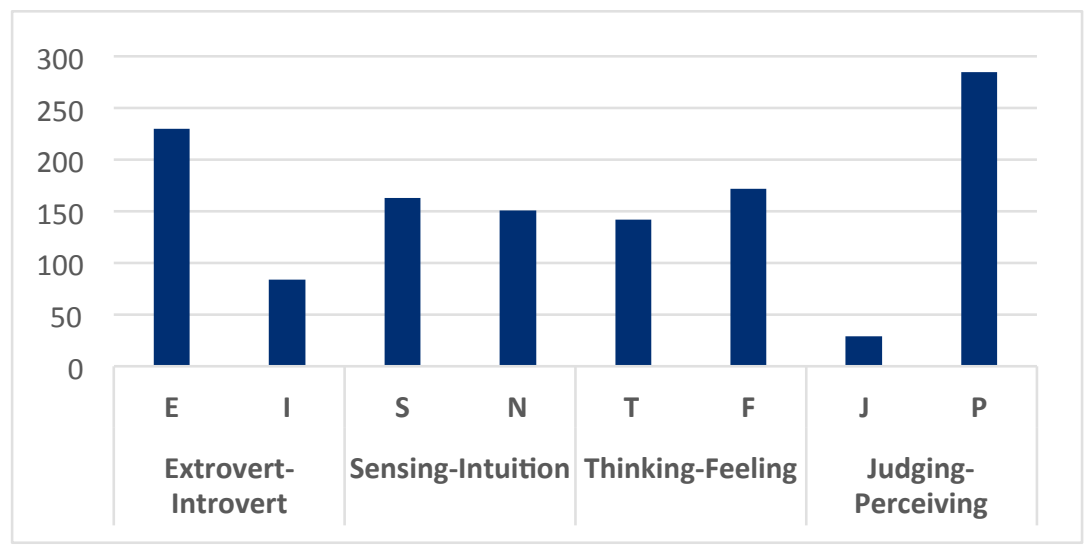

Figure 1. CIS Major Personality Types

The study found that there are differences in grade distribution based upon the student's personality type. Table 3 and Figure 2 show the average grade distribution by MBTI type. Hypothesis 1 was rejected, the results of the chisquare test indicated that the grades were not the same across the various categories. Further analysis was performed on each of the four subcategory. These results are shown in Table 4.

Table 3: Average Grade by Personality Type

\begin{tabular}{|r|r|r|r|r|r|r|}
\hline MBTI & Mean & Std. Dev. & & MBTI & Mean & Std. Dev. \\
\hline ENFJ & 83.27 & 13.353 & & INFJ & 83.03 & 12.562 \\
ENFP & 84.61 & 13.862 & & INFP & 81.38 & 13.347 \\
ENTJ & 84.16 & 12.631 & & INTJ & 82.36 & 12.624 \\
ENTP & 85.48 & 12.779 & & INTP & 83.78 & 14.291 \\
ESFJ & 88.20 & 9.834 & & ISFJ & 84.83 & 7.548 \\
ESFP & 65.00 & 15.969 & & ISFP & 73.39 & 14.782 \\
ESTJ & 80.67 & 17.885 & & ISTJ & 80.35 & 12.208 \\
ESTP & 76.86 & 19.377 & & ISTP & 72.25 & 19.821 \\
\hline
\end{tabular}




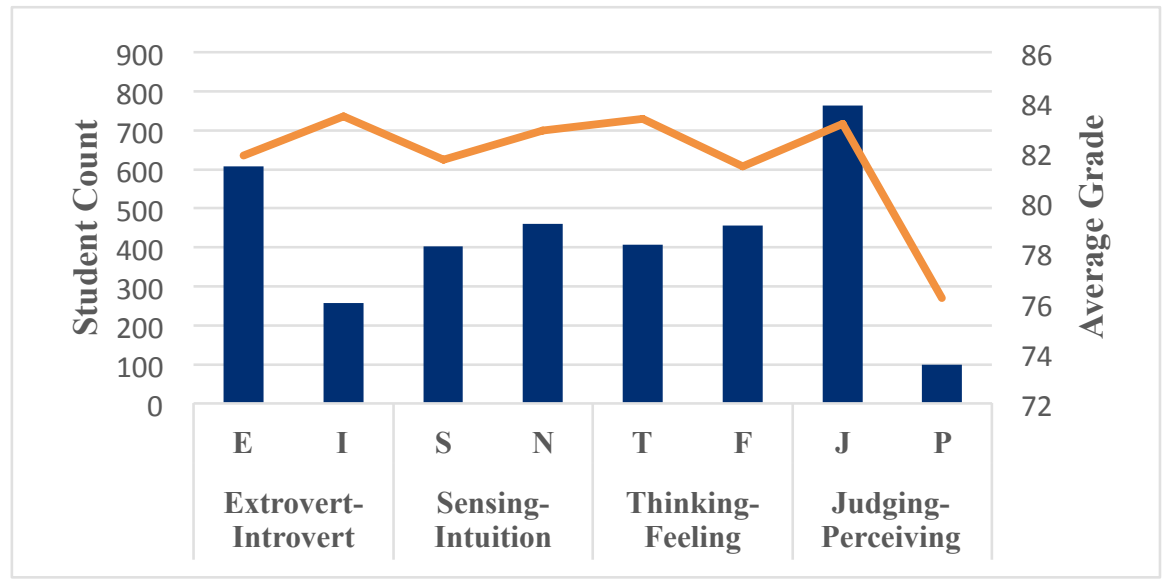

Figure 2. Sample Personality Type and Average Grade

Table 4. Statistical Results Based on Personality Dimensions

\begin{tabular}{|c|c|c|c|c|c|c|}
\hline \multirow{2}{*}{\multicolumn{2}{|c|}{ Model }} & \multicolumn{2}{|c|}{ Unstandardized Coefficients } & \multirow{2}{*}{$\begin{array}{c}\text { Standardized } \\
\text { Coefficients } \\
\text { Beta } \\
\end{array}$} & \multirow[b]{2}{*}{$\mathrm{t}$} & \multirow[b]{2}{*}{ Sig. } \\
\hline & & B & Std. Error & & & \\
\hline \multirow[t]{2}{*}{1} & (Constant) & 83.459 & .854 & & 97.719 & .000 \\
\hline & $\mathrm{E}$ or I & -1.584 & 1.019 & -.053 & -1.555 & .120 \\
\hline \multirow[t]{2}{*}{1} & (Constant) & 81.730 & .682 & \multirow[b]{2}{*}{.042} & 119.770 & .000 \\
\hline & $\mathrm{N}$ or $\mathrm{S}$ & 1.156 & .934 & & 1.237 & 216 \\
\hline \multirow[t]{2}{*}{1} & (Constant) & 81.451 & .640 & \multirow[b]{2}{*}{.069} & 127.301 & .000 \\
\hline & $\mathrm{T}$ or $\mathrm{F}$ & 1.901 & .932 & & 2.039 & .042. \\
\hline \multirow[t]{2}{*}{1} & (Constant) & 83.151 & .489 & \multirow[b]{2}{*}{-.162} & 169.881 & .000 \\
\hline & $\mathrm{P}$ or $\mathrm{J}$ & -6.951 & 1.439 & & 2.039 & .000 \\
\hline
\end{tabular}

a. Dependent Variable: Numeric Grade

Overall results showed that while introverts (83.5) had a higher overall average over extroverts (81.0), the difference was not statistically significant ( $\mathrm{p}$-value $=.12$ ) Therefore, Hypothesis 2 was rejected. A p-value of less than 0.10 is commonly accepted for social science research. Extraverts are usually more involved in the "outer world" of people and things and are usually social and get their energy from others. Conversely, Introverts are in the inner world of concepts and ideas and generally need to spend more time alone than Extraverts. Teague's research found that the most preferred characteristics for a system analyst are both Extroversion and iNtuition; while the ideal type of programmer is an ISTJ type [17]. The result (introverts generally doing better than extraverts but the difference not being significant) is consistent with Rosati's findings for engineering students [14].

For the personality trait, sensing versus intuition, there was no significant impact with $\mathrm{p}$ at .238 . So Hypothesis 3 was rejected. Sensing deals with how you perceive the world. Do you take more into account information that comes in through your five senses (Sensing), or do you pay more attention to the patterns and possibilities that you see in the information you receive (Intuition)? Felder and Brent observed that students will perform differently depending on the way they naturally prefer to process information [4]. If memory and recall are important, Sensing 


\section{Issues in Information Systems \\ Volume 15, Issue II, pp. 383-392, 2014}

types should perform better, while if analysis is required, intuitive students should have an advantage. In relating to CIS majors, this further supports Teague's conclusions, in that Intuition is the preferred characteristic of system analysts and ISTJ (sensing) types are preferred for programmers [17]. Further research should be done to see if there is a difference within the courses. Russo and Kaynama also found no statistical relationship between business capstone course performance and EI and SN scores [15].

Results in the thinking versus feeling personality trait were significant at a p-value of .042 . Hypothesis 4 was supported. Thinkers outperformed Feelers with an average of 83.4 versus 81.5. Thinkers prefer to make decisions logically, analytically, and objectively, while Feeling types prefer to make decisions with consideration for the impact on the people involved. Feeling types make decisions more subjectively based on personal values. Thinkers make decisions more on principles, while feelers make decisions more on values. This result is consistent with prior research on some of the STEM courses, such as calculus, physics and chemistry [4]. It also consistent with the personality types that were found to be suited toward technology-based majors (INTP, ESTP, ENTP and INTJ) [3, 18]. These findings were opposite for Russo's business capstone course where Feelers outperformed Thinkers [15].

The results suggest a very significant correlation between those the judging versus perceiving type students and higher grade scores. The results were significant at $\mathrm{p}<.001$; Hypothesis 5 was supported. Judgers (83.1) scored significantly higher overall course scores that Perceivers (76.1). Judging types prefer things orderly, scheduled, neat and organized. Perceiving types prefer things to be spontaneous, flexible, and prefer to keep their options open. Similarly, the dichotomous pair of feeling and judging of the study participants refers to an individual who is organized, orderly and works according to a set schedule. Felder observed that engineering students that were judging types scored significantly higher than the perceivers in diligence and self-discipline, time management, and attention to academic tasks [4].

\section{CONCLUSIONS AND FURTHER RESEARCH}

The results of this study indicate that course performance of groups of students are different relative to their personality type. In this study, Feeling type students performed better than Thinking types, and Judging types performed better than perceiving types. Practitioners may find personality testing to be useful in employment decisions, though other supporting studies should be undertaken prior to this recommendation. Employers may want to consider hiring candidates who are Thinkers, Judgers, and perhaps Introverts for improved employment productivity and success.

Further research will be done to see if personality type has effect on specific course performance. Also, further research analyzing the temperaments (NF, NT, SJ and SP) play a role in student success.

\section{REFERENCES}

1. Ayoubi, R.M., \& Ustwani, B. (2014). The Relationship between Student's MBTI, Preferences and Academic Performance at a Syrian University. Education and Training, 56(1), 78-90.

2. Dehghanzade, H., Moradi, M. A., \& Raghibi, M. (2011, November). A Survey of Human Factors' Impacts on the Effectiveness of Accounting Information Systems. International Journal of Business Administration, 2(4), 166-174.

3. DiTiberio,J. \& Hammer, A. (1993) Introduction to Type in College. Mountain View, CA: CPP, Inc.

4. Felder, R. and Brent, R. (2005), Understanding student differences, Journal of Engineering Education, 91(1), 58-72.

5. Gardner, W.L., \& Martinko, M.J. (1996, February). Using the Myers Briggs Type Indicator to Study Managers: A Literature Review and Research Agenda. The Journal of Management, 22(1), 45-83.

6. Institute for Management Excellence (2003, July). Understanding Personality Differences. Retrieved April 23, 2014, from ITsTime.com: http://www.itstime.com/jul2003.htm.

7. Jung, C. G. (1971). Psychological Types: The collected works of CG Jung (Vol. 6). Princeton, NJ, USA: Princeton University Press.

8. Kaluzniacky, E. (2004). Myers-Briggs Personality Types. In Managing Psychological Factors in Information Systems Work: An Orientation to Emotional Intelligence. (pp. 3-61). Hershey, PA, USA: Information Science Publishing. 


\section{Issues in Information Systems}

Volume 15, Issue II, pp. 383-392, 2014

9. Livingood, R.A. (2003). Predicting Success of Potential Information Technology Professionals by Correlation to the Myers-Briggs Type Indicator (Doctoral dissertation, Capella University). Retrieved from http://202.28.199.34/multim/3112985.pdf.

10. Lyons, M.L. (1985, August). The DP Psyche. Datamation, 31(16), 103-110.

11. McPherson, B. \& Mensch, S. (2007). Students' Personality Type and Choice of Major. Academy of Information and Management Sciences Journal, 10(2), 1-18.

12. Montequin, V.R., Balsera, J.V., Fernandez, J.M., \& Nieto, A.G. (2012). Using Myers-Briggs Type Indicator (MBTI) as a Tool for Setting up Student Teams for Information Technology Projects. Journal of Information Technology and Application in Education, 1(1), 28-34.

13. Myers \& Briggs Foundation, MBTI Basics retrieved May 9, 2014 from: http://www.myersbriggs.org/my-mbtipersonality-type/mbti-basics/

14. Rosati, P. (1997). Psychological Types of Canadian Engineering Students. Journal of Psychological Type, 41, 33-37.

15. Russo, C. \& Kaynama, S. (2012). The Impact of Personality Type and Gender on Student's Performance in a Business Capstone Course, Academy of Educational Leadership Journal, 16(1).

16. Sterling, G.D., \& Brinthaupt, T. M. (2003). Faculty and Industry Conceptions of Successful Computer Programmers. Journal of Information Systems Education, 14(4), 417-424.

17. Teague, G.J. (1998). Personality Type, Career Preference, and Implications for Computer Science Recruitment and Teaching. Proceedings of the Australian Computer Science Education Conference (pp. 155-163). Brisbane: The Association of Computing Machinery.

18. University of Toledo, MBTI and Major Choice (2005, February). Retrieved April 28, 2014 from: http://www.utoledo.edu/success/career/pdfs/MBTI TYPE TABLE Majors 2.pdf.

19. Weldon, D. (1995, May). A Mutual Understanding. Computerworld, 29(18), 103-111.

20. Wheeler, P. R., Hunton, J. E. \& Bryant, S. M. (2004). Accounting Information Systems Research Opportunities Using Personality Type Theory \& the Myers-Briggs Type Indicator. Journal of Information Systems 18(1): 1. 


\section{APPENDIX A: The 16 MBTI $^{\circledR}$ Types}

\section{ISTJ}

Quiet, serious, earn success by thoroughness and dependability. Practical, matter-of-fact, realistic, and responsible. Decide logically what should be done and work toward it steadily, regardless of distractions. Take pleasure in making everything orderly and organized - their work, their home, their life. Value traditions and loyalty.

\section{ISF J}

Quiet, friendly, responsible, and conscientious. Committed and steady in meeting their obligations. Thorough, painstaking, and accurate. Loyal, considerate, notice and remember specifics about people who are important to them, concerned with how others feel. Strive to create an orderly and harmonious environment at work and at home.

\section{INFJ}

Seek meaning and connection in ideas, relationships, and material possessions. Want to understand what motivates people and are insightful about others. Conscientious and committed to their firm values. Develop a clear vision about how best to serve the common good. Organized and decisive in implementing their vision.

\section{INTJ}

Have original minds and great drive for implementing their ideas and achieving their goals. Quickly see patterns in external events and develop long-range explanatory perspectives. When committed, organize a job and carry it through. Skeptical and independent, have high standards of competence and performance - for themselves and others.

\section{ISTP}

Tolerant and flexible, quiet observers until a problem appears, then act quickly to find workable solutions. Analyze what makes things work and readily get through large amounts of data to isolate the core of practical problems. Interested in cause and effect, organize facts using logical principles, value efficiency.

\section{ISFP}

Quiet, friendly, sensitive, and kind. Enjoy the present moment, what's going on around them. Like to have their own space and to work within their own time frame. Loyal and committed to their values and to people who are important to them. Dislike disagreements and conflicts, do not force their opinions or values on others.

\section{INFP}

Idealistic, loyal to their values and to people who are important to them. Want an external life that is congruent with their values. Curious, quick to see possibilities, can be catalysts for implementing ideas. Seek to understand people and to help them fulfill their potential. Adaptable, flexible, and accepting unless a value is threatened.

\section{INTP}

Seek to develop logical explanations for everything that interests them. Theoretical and abstract, interested more in ideas than in social interaction. Quiet, contained, flexible, and adaptable. Have unusual ability to focus in depth to solve problems in their area of interest. Skeptical, sometimes critical, always analytical.

\section{ESTP}

Flexible and tolerant, they take a pragmatic approach focused on immediate results. Theories and conceptual explanations bore them - they want to act energetically to solve the problem. Focus on the here-and-now, spontaneous, enjoy each moment that they can be active with others. Enjoy material comforts and style. Learn best through doing. 


\section{ESFP}

Outgoing, friendly, and accepting. Exuberant lovers of life, people, and material comforts. Enjoy working with others to make things happen. Bring common sense and a realistic approach to their work, and make work fun. Flexible and spontaneous, adapt readily to new people and environments. Learn best by trying a new skill with other people.

\section{ENFP}

Warmly enthusiastic and imaginative. See life as full of possibilities. Make connections between events and information very quickly, and confidently proceed based on the patterns they see. Want a lot of affirmation from others, and readily give appreciation and support. Spontaneous and flexible, often rely on their ability to improvise and their verbal fluency.

\section{ENTP}

Quick, ingenious, stimulating, alert, and outspoken. Resourceful in solving new and challenging problems. Adept at generating conceptual possibilities and then analyzing them strategically. Good at reading other people. Bored by routine, will seldom do the same thing the same way, apt to turn to one new interest after another.

\section{ESTJ}

Practical, realistic, matter-of-fact. Decisive, quickly move to implement decisions. Organize projects and people to get things done, focus on getting results in the most efficient way possible. Take care of routine details. Have a clear set of logical standards, systematically follow them and want others to also. Forceful in implementing their plans.

\section{ESFJ}

Warmhearted, conscientious, and cooperative. Want harmony in their environment, work with determination to establish it. Like to work with others to complete tasks accurately and on time. Loyal, follow through even in small matters. Notice what others need in their day-by-day lives and try to provide it. Want to be appreciated for who they are and for what they contribute.

\section{ENFJ}

Warm, empathetic, responsive, and responsible. Highly attuned to the emotions, needs, and motivations of others. Find potential in everyone, want to help others fulfill their potential. May act as catalysts for individual and group growth. Loyal, responsive to praise and criticism. Sociable, facilitate others in a group, and provide inspiring leadership.

\section{ENTJ}

Frank, decisive, assume leadership readily. Quickly see illogical and inefficient procedures and policies, develop and implement comprehensive systems to solve organizational problems. Enjoy long-term planning and goal setting. Usually well informed, well read, enjoy expanding their knowledge and passing it on to others. Forceful in presenting their ideas.

Source: The Myers \& Briggs Foundation: http://www.myersbriggs.org/my-mbti-personality-type/mbti-basics/the16-mbti-types.asp 
Issues in Information Systems

Volume 15, Issue II, pp. 383-392, 2014

APPENDIX B: MBTI and Major Choice

\begin{tabular}{|c|c|c|c|}
\hline $\begin{array}{l}\text { ISTJ } \\
\text { Accounting } \\
\text { Biology } \\
\text { Criminal Justice } \\
\text { Finance } \\
\text { Exercise Science } \\
\text { Geology } \\
\text { Medical Technology } \\
\text { Civil engineering }\end{array}$ & $\begin{array}{l}\text { ISFJ } \\
\text { Criminal Justice } \\
\text { Psychology } \\
\text { Finance } \\
\text { History } \\
\text { Medical Technology } \\
\text { Religious Studies } \\
\text { Social Work }\end{array}$ & $\begin{array}{l}\text { INFJ } \\
\text { Art } \\
\text { Communication } \\
\text { Psychology } \\
\text { Latin American } \\
\text { Studies } \\
\text { Marketing } \\
\text { Nursing } \\
\text { Physical Education } \\
\text { Sociology } \\
\text { Urban Studies }\end{array}$ & $\begin{array}{l}\text { INTJ } \\
\text { Biochemistry } \\
\text { Psychology } \\
\text { Finance } \\
\text { Mathematics } \\
\text { Sociology } \\
\text { Urban Studies } \\
\text { Environmental Sciences } \\
\text { Business Management } \\
\text { Technology }\end{array}$ \\
\hline $\begin{array}{l}\text { ISTP } \\
\text { Biology } \\
\text { Finance } \\
\text { Law and Social } \\
\text { Thought } \\
\text { Geology } \\
\text { Economics } \\
\text { Theatre } \\
\text { Mathematics }\end{array}$ & $\begin{array}{l}\text { ISFP } \\
\text { Art } \\
\text { Psychology } \\
\text { Exercise Science } \\
\text { Law and Social } \\
\text { Thought } \\
\text { Foreign Languages } \\
\text { Nursing }\end{array}$ & $\begin{array}{l}\text { INFP } \\
\text { Management } \\
\text { History } \\
\text { Medical Technology } \\
\text { Foreign Languages } \\
\text { Music } \\
\text { Psychology } \\
\text { Religious Studies } \\
\text { Social Work }\end{array}$ & $\begin{array}{l}\text { INTP } \\
\text { Chemistry } \\
\text { Information Systems } \\
\text { Criminal Justice } \\
\text { Economics } \\
\text { Finance } \\
\text { History } \\
\text { Legal Secretarial } \\
\text { Technology } \\
\text { Physics }\end{array}$ \\
\hline $\begin{array}{l}\text { ESTP } \\
\text { Art } \\
\text { Biology } \\
\text { Information Systems } \\
\text { Medical Technology } \\
\text { Environmental Studies } \\
\text { Theatre }\end{array}$ & $\begin{array}{l}\text { ESFP } \\
\text { Psychology } \\
\text { Exercise Science } \\
\text { Geology } \\
\text { Nursing } \\
\text { Speech Language } \\
\text { Pathology } \\
\text { Social Work }\end{array}$ & $\begin{array}{l}\text { ENFP } \\
\text { Anthropology } \\
\text { Art } \\
\text { Chemistry } \\
\text { Early Childhood } \\
\text { Education } \\
\text { Marketing } \\
\text { Foreign Languages } \\
\text { Sociology } \\
\text { Communication }\end{array}$ & $\begin{array}{l}\text { ENTP } \\
\text { Information Technology } \\
\text { Communication } \\
\text { Criminal Justice } \\
\text { Finance } \\
\text { Mechanical Engineering } \\
\text { Technology } \\
\text { Marketing } \\
\text { History }\end{array}$ \\
\hline $\begin{array}{l}\text { ESTJ } \\
\text { Mechanical } \\
\text { Engineering } \\
\text { Public Relations } \\
\text { Music } \\
\text { Accounting } \\
\text { Finance } \\
\text { Political Science }\end{array}$ & $\begin{array}{l}\text { ESFJ } \\
\text { Psychology } \\
\text { Marketing } \\
\text { Nursing } \\
\text { Physical Education } \\
\text { Religious Studies } \\
\text { Social Work } \\
\text { Speech Language } \\
\text { Pathology }\end{array}$ & $\begin{array}{l}\text { ENFJ } \\
\text { Communication } \\
\text { Psychology } \\
\text { Management } \\
\text { Marketing } \\
\text { Public Relations } \\
\text { Urban Studies } \\
\text { Foreign Languages }\end{array}$ & $\begin{array}{l}\text { ENTJ } \\
\text { Economics } \\
\text { Secondary Education } \\
\text { Management } \\
\text { International Business } \\
\text { Political Science } \\
\text { Sociology } \\
\text { Anthropology }\end{array}$ \\
\hline
\end{tabular}

Source: The University of Toledo Career Services, February 2005 